\title{
Assessment of Public Awareness on Common Zoonotic Diseases in Lalo Kile District, Kellem Wollega Zone, Ethiopia
}

\author{
Gemechu Berhanu Kerorsa \\ College of Agriculture and Veterinary Medicine, Dambi Dollo University, Dambi Dollo, Ethiopia \\ Email address: \\ gemechuberhanu@yahoo.com
}

To cite this article:

Gemechu Berhanu Kerorsa. Assessment of Public Awareness on Common Zoonotic Diseases in Lalo Kile District, Kellem Wollega Zone, Ethiopia. International Journal of Biomedical Engineering and Clinical Science. Vol. 5, No. 4, 2019, pp. 59-64.

doi: 10.11648/j.ijbecs.20190504.11

Received: August 19, 2019; Accepted: October 30, 2019; Published: November 7, 2019

\begin{abstract}
A questionnaire based cross sectional survey was conducted to assess the awareness of the community about common zoonotic diseases in Lalo Kile District, Kellem Wollega Zone, Ethiopia. A total of 440 (292 male and 148 female) respondents were participated during the interview. A structured questionnaire was prepared and used to ask the respondents categorized into different levels about their knowledge and awareness on common zoonotic diseases in the area. From the total respondent category $82.50 \%$ have awareness on rabies, $81.82 \%$ have a concept about taeniasis, $81.36 \% \mathrm{know}$ about bovine tuberculosis, $79.55 \%$ know about anthrax and 72.05\% know about hydatidosis. These respondents have a concept about transmission, clinical signs, effect and way of control and prevention of the common zoonotic diseases. From the different category of the respondents, educational level and occupational status are statistically significant $(\mathrm{P}<0.05)$. $83.86 \%$ and $86.36 \%$ of the respondents consume raw meat and raw milk, respectively. Most of the respondents know that zoonotic diseases can be transmitted from animals to human, but very few of them know that the disease can be transmitted from human to animals. Therefore, the general continuous awareness creation and teaching of the community about zoonotic disease is very important.
\end{abstract}

Keywords: Awareness, Lalo Kile, Prevalence, Public, Zoonotic

\section{Introduction}

Zoonotic diseases are diseases that can be transmitted and distributed between animals harboring the disease and humans, and having different public health burdens and it is known that $75 \%$ of emerging pathogens fall within the category of zoonotic diseases [1]. These zoonotic diseases are widely distributed in Ethiopia and include bovine tuberculosis, taeniasis, hydatidosis [2], and rabies [3]. Many zoonotic diseases are caused by organisms such as bacteria, viruses, fungi, protozoa and other parasites, with both domestic and wild animals acting as reservoirs for the pathogens. Most of them cause health problems in human showing different clinical signs and if not treated may cause death [4].

People are mainly dependent on animals and animal products and they have very close relationship or contact with animals. They use raw animal products as source of feed that may predispose them to zoonotic diseases and different infections [5]. The large effect on human health and livelihood, many cases of illness and large amount of death every year, is caused by endemic zoonoses that are persistent health problems all over the world [6].

Zoonotic diseases can be transmitted in a different ways including air (aerosol), direct contact, contact with an inanimate object that harbors the disease, oral ingestion and insect transmission [7]. In both developing and developed countries, emergence of new zoonoses might be the result of either newly identified pathogens or agents that are already known, usually appearing in animal species in which the disease had not formerly been detected [8].

The public awareness and understanding in the public those having contact with animals and use animal product has received much attention now days and it is somewhat 
helpful for reduction of transmission of zoonotic diseases. Hence, building of well-governed public health and animal health system, emphasizing the importance of cross-sectoral collaboration and coordination, abandon of traditional behaviors that can prone to zoonotic diseases and commitment of decision makers to obtain the necessary political, legal and financial support are required issues in minimizing of the impact of zoonotic diseases [2, 9-10]. In the area even though zoonotic diseases were widely observed, most people have contact with animals and consumes feed of animal origin including consumption of raw meat and raw milk. The objective of this study was to assess the awareness of the public on the common zoonotic diseases in the study area.

\section{Materials and Methods}

\subsection{Study Area}

The study was conducted in Lalo Kile District of Kellem Wollega Zone, Oromia Regional State, Ethiopia. The district is geographically found at $08^{\circ} 45^{\prime}$ to $08^{\circ} 59^{\prime}$ latitude and North of equator, and $035^{\circ} 26^{\prime}$ East longitudes, and located at distance of $535 \mathrm{Km}$ West of Addis Ababa. Altitude of the study area ranges from 500-1800 m. a. s. 1., temperature ranges from $15^{\circ} \mathrm{C}$ (minimum) to $32^{\circ} \mathrm{C}$ (maximum) and has rainfall ranging from $1000 \mathrm{ml}$ to $1500 \mathrm{ml}$ [11].

\subsection{Study Design}

A cross-sectional study design using questionnaire and interview was used to assess the awareness of the public on zoonotic diseases such as tuberculosis, anthrax, hydatidosis, taeniasis and rabies from January, 2017 to May, 2017.

\subsection{Study Population}

The study populations were residents of Lalo Kile District of Kellem Wollega Zone, including those people who use foods of animal origin and also have contact with animals. The population of the district were 32,688 male and 33,710 female, totally 66,398 [12].

\subsection{Study Methodology}

A semi-structured questionnaire was used for the interview of the respondents to evaluate the awareness of the community about the common zoonotic disease using questionnaire translated to the local language of the study area, Afaan Oromoo. The questionnaire contained knowledge about zoonotic diseases, the way of their transmission and clinical signs they show. Also the respondents were interviewed if they have deep knowledge on common zoonotic diseases including rabies, tuberculosis, anthrax, brucellosis, hydatidosis and Taeniasis, and additionally their status on the consumption of raw meat and raw milk.

\subsection{Data Collection}

A total of 440 respondents were interviewed in face to face. A questionnaire which was semi-structured was prepared in English and translated in the local language of the community, Afaan Oromoo, containing different community based questions that can assess the levels of their awareness towards common bacterial and viral zoonotic diseases. Simple random sampling technique was used as a method of data collection to select respondents required for the interview purpose.

\subsection{Data Analysis}

The collected data were entered into Microsoft excel spread sheet and were analyzed using SPSS version 20. Frequency and percentage were taken by computing descriptive statistics. A Pearson Chi-Square test was used to evaluate the presence of statistical significance of difference in the study. A P-value $<0.05$ was considered as significant.

\section{Results}

\subsection{Category of the Respondents}

The respondents were randomly selected from the study area and they were categorized depending on (table 1) sex as male $292(66.36 \%)$ and female 148 (33.64\%); age as young 101 (22.95\%), adult $215(48.86 \%)$ and old 124 (28.18\%); educational status or level as illiterate $97(22.05 \%)$, read and write $33(7.50 \%)$, elementary and high school 151 (34.32\%), and college and university 159 (36.14\%), and also occupation as farmers $129(29.32 \%)$, health workers $18(4.09 \%)$, student $152(34.55 \%)$ and other professionals 141 (32.05\%).

Table 1. Category of the respondents in number and percentage.

\begin{tabular}{|c|c|c|c|c|}
\hline Criteria & Category & Number & Percentage (\%) & P-value \\
\hline \multirow{2}{*}{ Sex } & Male & 292 & 66.36 & \multirow{2}{*}{0.099} \\
\hline & Female & 148 & 33.64 & \\
\hline \multirow{3}{*}{ Age } & Young & 101 & 22.95 & \multirow{3}{*}{0.020} \\
\hline & Adult & 215 & 48.86 & \\
\hline & Old & 124 & 28.18 & \\
\hline \multirow{4}{*}{ Educational status } & Illiterate & 97 & 22.05 & \multirow{4}{*}{0.000} \\
\hline & Read and Write & 33 & 7.50 & \\
\hline & Elementary and High school & 151 & 34.32 & \\
\hline & College and University & 159 & 36.14 & \\
\hline \multirow{4}{*}{ Occupation } & Farmers & 129 & 29.32 & \multirow{4}{*}{0.000} \\
\hline & Health workers & 18 & 4.09 & \\
\hline & Student & 152 & 34.55 & \\
\hline & Other professionals & 141 & 32.05 & \\
\hline
\end{tabular}




\subsection{The Overall Awareness of the Community on the Common Zoonotic Diseases}

From all the respondents (table 2) $358(81.36 \%), 350$ (79.55\%), 317 (72.05), $360(81.82 \%)$ and $363(82.50 \%)$ respondents have awareness on the bovine tuberculosis, anthrax, hydatidosis, taeniasis and rabies respectively.

Table 2. The overall percentage of the community in the study area having awareness on the common zoonotic diseases.

\begin{tabular}{lll}
\hline $\begin{array}{l}\text { Common zoonotic } \\
\text { diseases }\end{array}$ & $\begin{array}{l}\text { Number of the community } \\
\text { having awareness }\end{array}$ & Percentage (\%) \\
\hline Tuberculosis & 358 & 81.36 \\
Anthrax & 350 & 79.55 \\
Hydatidosis & 317 & 72.05 \\
Taeniasis & 360 & 81.82 \\
Rabies & 363 & 82.50 \\
\hline
\end{tabular}

\subsection{Public Awareness About Bovine Tuberculosis}

According to the study (table 3), 231 (79.11\%) male respondents, $127(85.81 \%)$ female respondents, $78(77.23 \%)$ young age, $185(85.05 \%)$ adult age, $95(76.61 \%)$ old age, 58 $(59.79 \%)$ illiterate respondents, $20(60.61 \%)$ people those can read and write, $129(85.43 \%)$ elementary and high school, 151 (94.97\%) college and university respondents, 77 $(59.69 \%)$ farmers, $18(100 \%)$ health workers, $130(85.53 \%)$ students and $133(94.33 \%)$ other professional have awareness on the transmission, clinical signs and the general concept of tuberculosis. Most of them knew that bovine tuberculosis affect cattle and can be transmitted to human through inhalation and consumption of raw milk and meat.

Table 3. Proportion of respondents having awareness about tuberculosis.

\begin{tabular}{llll}
\hline Criteria & Category & Number having awareness & Percentage (\%) \\
\hline \multirow{2}{*}{ Sex } & Male & 231 & 79.11 \\
& Female & 127 & 85.81 \\
Age & Young & 78 & 77.23 \\
& Adult & 185 & 85.05 \\
& Old & 95 & 76.61 \\
Educational status & Read and Write & 58 & 59.79 \\
& Elementary and High school & 20 & 60.61 \\
& College and University & 129 & 85.43 \\
& Farmers & 151 & 94.97 \\
Occupation & Health workers & 77 & 59.69 \\
& Student & 18 & 100 \\
& Other professionals & 130 & 85.53 \\
\hline
\end{tabular}

\subsection{Public Awareness About Anthrax}

Accordingly (table 4), 227 (77.74\%) male respondents, $123(83.11 \%)$ female respondents, $77(76.24 \%)$ young age, $181(84.19 \%)$ adult age, $92(74.19 \%)$ old age, $56(57.73 \%)$ illiterate respondents, 17 (51.52\%) people those can read and write, $126(83.44 \%)$ elementary and high school, 151
(94.97\%) college and university respondents, 72 (55.81\%) farmers, $18(100 \%)$ health workers, $126(82.89 \%)$ students and $135(95.74 \%)$ other professional have awareness on the transmission, clinical signs and the general concept of Anthrax. They have gotten the awareness through mass media, radio, television, at school and through different information sources.

Table 4. Proportion of respondents having awareness about anthrax.

\begin{tabular}{|c|c|c|c|c|}
\hline Criteria & Category & Number having awareness & Percentage (\%) & P-value \\
\hline \multirow{2}{*}{ Sex } & Male & 227 & 77.74 & \multirow{2}{*}{0.187} \\
\hline & Female & 123 & 83.11 & \\
\hline \multirow{3}{*}{ Age } & Young & 77 & 76.24 & \multirow{3}{*}{0.058} \\
\hline & Adult & 181 & 84.19 & \\
\hline & Old & 92 & 74.19 & \\
\hline \multirow{4}{*}{ Educational status } & Illiterate & 56 & 57.73 & \multirow{4}{*}{0.000} \\
\hline & Read and Write & 17 & 51.52 & \\
\hline & Elementary and High school & 126 & 83.44 & \\
\hline & College and University & 151 & 94.97 & \\
\hline \multirow{4}{*}{ Occupation } & Farmers & 72 & 55.81 & \multirow{4}{*}{0.000} \\
\hline & Health workers & 18 & 100 & \\
\hline & Student & 126 & 82.89 & \\
\hline & Other professionals & 135 & 95.74 & \\
\hline
\end{tabular}

\subsection{Public Awareness About Hydatidosis}

From the total respondents (table 5), 204 (69.86\%) male respondents, $112(75.68 \%)$ female respondents, $65(64.36 \%)$ young age, $171(79.53 \%)$ adult age, $80(64.52 \%)$ old age, 47 $(48.45 \%)$ illiterate respondents, $16(48.48 \%)$ people those can read and write, $106(70.02 \%)$ elementary and high school, 147 (92.45\%) college and university respondents, 62 
(48.06\%) farmers, $18(100 \%)$ health workers, 107 (70.36\%) students and $130(92.20 \%)$ other professional have awareness on the transmission, clinical signs and the general concept of hydatidosis, but most of them consumed raw meat.

Table 5. Proportion of respondents having awareness about hydatidosis.

\begin{tabular}{|c|c|c|c|c|}
\hline Criteria & Category & Number having awareness & Percentage (\%) & P-value \\
\hline \multirow{2}{*}{ Sex } & Male & 204 & 69.86 & \multirow{2}{*}{0.200} \\
\hline & Female & 112 & 75.68 & \\
\hline \multirow{3}{*}{ Age } & Young & 65 & 64.36 & \multirow{3}{*}{0.002} \\
\hline & Adult & 171 & 79.53 & \\
\hline & Old & 80 & 64.52 & \\
\hline \multirow{3}{*}{ Educational status } & Illiterate & 47 & 48.45 & \multirow{3}{*}{0.000} \\
\hline & Read and Write & 16 & 48.48 & \\
\hline & College and University & 147 & 92.45 & \\
\hline \multirow{4}{*}{ Occupation } & Farmers & 62 & 48.06 & \multirow{4}{*}{0.000} \\
\hline & Health workers & 18 & 100 & \\
\hline & Student & 107 & 70.36 & \\
\hline & Other professionals & 130 & 92.20 & \\
\hline
\end{tabular}

\subsection{Public Awareness About Taeniasis}

Among total respondents (table 6), 230 (78.77\%) male respondents, $130(87.84 \%)$ female respondents, $77(76.24 \%)$ young age, 189 (87.91\%) adult age, $94(75.81 \%)$ old age, 58 $(59.79 \%)$ illiterate respondents, $19(57.58 \%)$ people those can read and write, $129(85.43 \%)$ elementary and high school, $154(96.86 \%)$ college and university respondents, 76 (58.91\%) farmers, $18(100 \%)$ health workers, $130(85.53 \%)$ students and $136(96.45 \%)$ other professional have awareness on the transmission, clinical signs and the general concept of taeniasis. Even though most of the respondents knew about taeniasis, consumption of raw meat was common in the community.

Table 6. Proportion of respondents having awareness about taeniasis.

\begin{tabular}{|c|c|c|c|c|}
\hline Criteria & Category & Number having awareness & Percentage (\%) & P-value \\
\hline \multirow{2}{*}{ Sex } & Male & 230 & 78.77 & \multirow{2}{*}{0.020} \\
\hline & Female & 130 & 87.84 & \\
\hline \multirow{3}{*}{ Age } & Young & 77 & 76.24 & \multirow{3}{*}{0.005} \\
\hline & Adult & 189 & 87.91 & \\
\hline & Old & 94 & 75.81 & \\
\hline \multirow{3}{*}{ Educational status } & Illiterate & 58 & 59.79 & \multirow{3}{*}{0.000} \\
\hline & Read and Write & 19 & 57.58 & \\
\hline & College and University & 154 & 96.86 & \\
\hline \multirow{4}{*}{ Occupation } & Farmers & 76 & 58.91 & \multirow{4}{*}{0.000} \\
\hline & Health workers & 18 & 100 & \\
\hline & Students & 130 & 85.53 & \\
\hline & Other professionals & 136 & 96.45 & \\
\hline
\end{tabular}

\subsection{Public Awareness About Rabies}

Of the total respondents (table 7), 234 (80.14\%) male respondents, $128(86.49 \%)$ female respondents, $79(78.22 \%)$ young age, $188(87.44 \%)$ adult age, $95(76.61 \%)$ old age, 60 $(61.86 \%)$ illiterate respondents, $19(57.58 \%)$ people those can read and write, $129(85.43 \%)$ elementary and high school, 154 (96.86\%) college and university respondents, 78 $(60.47 \%)$ farmers, $18(100 \%)$ health workers, $130(85.53 \%)$ students and $137(97.16 \%)$ other professional have awareness on the transmission, clinical signs and the general concept of rabies. Most of them knew that rabies can be transmitted through dogs and other animals bite and madness as the clinical sign of the disease.

Table 7. Proportion of respondents having awareness about rabies.

\begin{tabular}{|c|c|c|c|c|}
\hline Criteria & Category & Number having awareness & Percentage (\%) & P-value \\
\hline \multirow{2}{*}{ Sex } & Male & 234 & 80.14 & \multirow{2}{*}{0.099} \\
\hline & Female & 128 & 86.49 & \\
\hline \multirow{3}{*}{ Age } & Young & 79 & 78.22 & \multirow{3}{*}{0.020} \\
\hline & Adult & 188 & 87.44 & \\
\hline & Old & 95 & 76.61 & \\
\hline \multirow{3}{*}{ Educational status } & Illiterate & 60 & 61.86 & \multirow{3}{*}{0.000} \\
\hline & Elementary and High school & 129 & 85.43 & \\
\hline & College and University & 154 & 96.86 & \\
\hline
\end{tabular}




\begin{tabular}{lllll}
\hline Criteria & Category & Number having awareness & Percentage (\%) & P-value \\
\hline \multirow{4}{*}{ Occupation } & Farmers & 78 & 60.47 & \\
& Health workers & 18 & 100 & 0.000 \\
& Student & 130 & 85.53 & \\
& Other professionals & 137 & 97.16 & \\
\hline
\end{tabular}

\section{Discussion}

In the study area the awareness on zoonotic diseases were rabies $(82.50 \%)$, taeniasis $(81.82 \%)$ tuberculosis $(81.36 \%)$, anthrax $(79.55 \%)$ and hydatidosis $(72.05 \%)$. This study showed that there was lower level of awareness on taeniasis and rabies as compared to the report of Tesfaye et al. (2013) [13] who reported $84.3 \%$ and $97.1 \%$, repectively in Jimma, Southwestern Ethiopia.

The study revealed the higher level of public awareness on bovine tuberculosis as compared to the study done by Tesfaye et al. (2013) [13] who reported 29.1\% in Jimma, Southwestern Ethiopia, and Bsrat et al. (2017) [14] who reported $49.50 \%$ in and Around Dodola Town, West Arsi Zone, Ethiopia; higher level of public awareness on anthrax as compared to the study done by Tesfaye et al. (2013) [13] who reported $55.4 \%$ in Jimma, Southwestern Ethiopia, and Bsrat et al. (2017) [14] who reported 50.8\% in and around Dodola Town, West Arsi Zone, Ethiopia.

According to this study, there was high level of public awareness on taeniasis and rabies in relation to the report done by Bsrat et al. (2017) [14] who reported 53.10\% and $68.8 \%$, respectively in and around Dodola Town, West Arsi Zone, Ethiopia, and also high level of public awareness on rabies in relation to the report done by Tensay et al. (2017) [15] who reported 71.9\% in Bishoftu, Ethiopia.

The percentage of respondents who consume raw meat and raw milk was higher as compared to the report done by Bsrat et al. (2017) [14] who reported $68.50 \%$ consumption of raw meat and $52.3 \%$ consumption of raw milk in and Around Dodola Town, West Arsi Zone, Ethiopia, and by Tesfaye et al. (2013) [13] who reported $66.8 \%$ consumption of raw milk in Jimma, Southwestern Ethiopia.

\section{Conclusion}

Zoonotic diseases are common diseases that need attention from the public in Ethiopia, especially in the study area. These diseases can be transmitted from animals to humans and vice versa in different ways including inhalation, ingestion or consumption of raw meat and milk, contact and other ways. They affects the health of the community and show different clinical signs, and sometimes death if not treated early. In this study, the awareness and knowledge of the community in the study area was assessed using questionnaire and interview. Accordingly, most of the respondents different status knew about the common zoonotic diseases. But some of some of them did not know about the common zoonotic diseases and some knowledge gap were observed. Therefore, continuous public awareness and teaching the community about zoonotic disease is very important.

\section{Conflict of Interest}

The author declares that there is no conflict of interest regarding this study.

\section{References}

[1] WHO, (2005). The Control of Neglected Zoonotic Diseases. Report of a Joint WHO/DFID-AHP Meeting with the participation of FAO and OIE. Geneva.

[2] Zewdie, W., Wario, E. and Tehetna, A. (2018). Assessment of Community Awareness on Common Zoonotic Disease in and around Yabello District of Oromia Regional State, Ethiopia. Multidisciplinary Advances in Veterinary Science, 2 (4): 388394.

[3] Hasano, E., Zeynalova, S., Geleishvili, M., Maes, E., Tongren, E., Marshall, E., Banyard, A., Mcelhinney, L. M., Whatmore, A. M., Fooks, A. R. And Horton, D. L. (2018.) Assessing the impact of public education on a preventable zoonotic disease: rabies. Epidemiol. Infect. 146: 227-235.

[4] DEFRA, (2003). Department for Environment, Food and Rural Affairs. Zoonoses Report United Kingdom, London. Pp. 23-27.

[5] Ameni, G. and Erkihun, A. (2007). Bovine on small-scale dairy farms in Adama Town, Central Ethiopia and farmers awareness of the disease. Revue Scientifique ET Technique 26 (3): 711-719.

[6] ILRI, (2012). International Livestock and Research Institute. Mapping of poverty and Likely zoonoses hotspot. Department for international development, UK, Nairobi, Kenya. Pp. 73-82.

[7] Kevin, D. and Nancy, C. (2009). Zoonotic Diseases of Cattle. Virginia Cooperative Extension programs publication. Pp. 400-460.

[8] Davis, J. R. and Ledenberg, J. (2001). Emerging infectious diseases from the global to the local perspective. A Summary of a Workshop of the Forum on Emerging Infections. National Academy Press Washington, D. C.

[9] Swai ES., Schoonman, L. and Daborn, C. J. (2010). Knowledge and attitude towards zoonoses among animal health workers and livestock keepers in Arusha and Tanga, Tanzania. Tanzania Journal of Health Research, 12 (4): 280-286.

[10] Mosalagae D., Pfukenyi, D. M. and Matope, G. (2011). Milk producers' awareness of milk-borne zoonoses in selected smallholder and commercial dairy farms of Zimbabwe. Trop. Anim. Health Prod., 43 (3): 733-739.

[11] LKDAO, (2017). Lalo Kile District Agricultural Office. Annual Report. 
[12] CSA, (2017). Central Statistical Agency. The Federal Democratic Republic of Ethiopia; central statistical agency, agricultural sample survey, 2016/17 (2009 E. C.), Volume II: Statistical Bulletin No. 585. CSA, Addis Ababa, Ethiopia. Pp. 107.

[13] Tesfaye, D., Fekede, D., Tigre, W., Regassa, A. and Fekadu, A. (2013). Perception of the public on common zoonotic diseases in Jimma, southwestern Ethiopia. International Journal of Medicine and Medical Science, 5 (6): 279-285.
[14] Bsrat, A., Gezmu, M. and Mekuria, A. (2017). Assessment of Community Knowledge, Attitude and Practice on Zoonotic Disease in and Around Dodola Town, West Arsi Zone, Ethiopia. Ethiopian Journal of Veterinary Science and Animal Production (EJVSAP), 1 (1): 57-65.

[15] Tensay, W. F. (2017). Household Knowledge, Attitudes and Practices Related to Pet Contact and Associated Zoonosis in Bishoftu, Ethiopia. Global Veterinaria, 18 (4): 277-285. 